\title{
Carbon dioxide efflux during the flooding phase of temporary ponds
}

\author{
Núria Catalán ${ }^{1,2}$, Daniel von Schiller ${ }^{3}$, Rafael Marcé3 ${ }^{3}$ Matthias Koschorreck ${ }^{4}$, \\ Lluís Gomez-Gener ${ }^{1}$ and Biel Obrador ${ }^{1, *}$
}

${ }^{1}$ Department of Ecology, University of Barcelona, Av. Diagonal 643, E-08028, Barcelona, Spain.

${ }^{2}$ Limnology/Dept of Ecology and Genetics, Evolutionary Biology Centre, Uppsala University, Sweden.

${ }^{3}$ Catalan Institute for Water Research, Carrer Emili Grahit, 101, 7003 Girona, Spain.

${ }^{4}$ Department Lake Research, Helmholtz Centre for Environmental Research-UFZ, Brückstrasse 3a, 39114 Magdeburg, Germany.

*Corresponding author: obrador@ub.edu

Received: 02/07/2014

Accepted: 07/10/2014

\begin{abstract}
Carbon dioxide efflux during the flooding phase of temporary ponds

Small water bodies, such as temporary ponds, have a high carbon processing potential. Nevertheless, despite the global occurrence of these systems, the carbon effluxes from such water bodies have been largely overlooked. In this study, we examined the intra- and intersystem variability of carbon dioxide $\left(\mathrm{CO}_{2}\right)$ effluxes from a set of Mediterranean temporary ponds during the flooding phase, a hot-spot for biogeochemical cycling in temporary systems. The $\mathrm{CO}_{2}$ effluxes showed higher variability among the various sections of each pond (i.e., inundated, emerged-unvegetated and emerged-vegetated) than among the ponds. The emerged-vegetated sections showed the highest $\mathrm{CO}_{2}$ effluxes per unit area and tended to drive the total effluxes at the whole-ecosystem scale. The mean $\mathrm{CO}_{2}$ efflux $\left(121.3 \pm 138.1 \mathrm{mmol} \mathrm{m}^{-2} \mathrm{~d}^{-1}\right)$ was in the upper range for freshwater ecosystems. The $\mathrm{CO}_{2}$ effluxes were not related to catchment properties but rather to the organic content of the sediments, especially in the emerged sections of the ponds. Our results indicate that temporary ponds, especially their emerged sections, are important sources of $\mathrm{CO}_{2}$ to the atmosphere, highlighting the need to include the dry phases of these and other temporary aquatic systems in regional carbon budgets.
\end{abstract}

Key words: Carbon fluxes, $\mathrm{CO}_{2}$ emissions, temporary ecosystems, temporary ponds.

\section{RESUMEN}

Flujos de dióxido de carbono durante la fase de inundación de estanques temporales

Los pequeños cuerpos de agua como los estanques temporales tienen un elevado potencial para procesar carbono. Sin embargo, a pesar de su presencia global, los flujos de carbono procedentes de estos sistemas han sido muy poco estudiados. En el presente trabajo, se estudió la variabilidad intra- e inter-sistémica de los flujos de dióxido de carbono $\left(\mathrm{CO}_{2}\right)$ en un conjunto de estanques temporales mediterráneos durante su fase de inundación, un momento en que los ciclos biogeoquímicos en sistemas temporales se intensifican. Las emisiones de $\mathrm{CO}_{2}$ presentaron una mayor variabilidad entre las diferentes secciones dentro de cada estanque (es decir, inundada, emergida-sin vegetación y emergida-vegetada) que entre los diferentes estanques. Las secciones emergidas-vegetadas mostraron las mayores emisiones de $\mathrm{CO}_{2}$ por unidad de superficie, siendo las principales responsables de las emisiones totales a escala ecosistémica. Las emisiones de $\mathrm{CO}_{2}$ (media $121.3 \pm 138.1 \mathrm{mmol} \mathrm{m}^{-2} \mathrm{~d}^{-1}$ ) corresponden al rango superior para ecosistemas de agua dulce. Las emisiones no mostraron relación con las características de la cuenca de captación de cada estanque, sino más bien con el contenido en materia orgánica de los sedimentos, especialmente en las secciones emergidas de los estanques. Nuestros resultados indican que los estanques temporales, especialmente sus secciones emergidas, son importantes fuentes de $\mathrm{CO}_{2}$ hacia la atmósfera, poniendo de manifiesto la necesidad de incluir las fases secas de éstos y otros sistemas acuáticos temporales en los balances regionales de carbono.

Palabras clave: Flujos de carbono, emisiones de $\mathrm{CO}_{2}$, ecosistemas temporales, estanques temporales. 


\section{INTRODUCTION}

Ecological processes in small aquatic ecosystems have been poorly studied to date because it has been assumed that small systems make a minor contribution to global processes (Downing, 2010). However, recent studies have drawn attention to these systems, arguing that small lakes and ponds not only dominate the areal extent of inland waters but also support disproportionately intense processes compared with larger ecosystems (Downing, 2009; Downing et al., 2006). For example, it has been shown that areal rates of carbon burial, oxygen depletion, and $\mathrm{CO}_{2}$ efflux are much higher in smaller than in larger water bodies (Dean \& Gorham, 1998; Downing et al., 2008; Kortelainen et al., 2006).

Temporary ponds are small inland water bodies that experience periodic emerged (no surface water) phases (Williams, 1997). They are well known to host a large number of rare and endemic species and are recognised as key ecosystems for biodiversity conservation (Miracle et al., 2010). Contrastingly, little is known about their biogeochemical functioning. Indeed, temporary ponds represent a particular case of a neglected ecosystem for biogeochemists, primarily because their temporary nature poses a challenge for the study of biogeochemical processes. In particular, although studies in Arctic landscapes have demonstrated that carbon effluxes to the atmosphere from temporary ponds can represent up to one-half of the regional emissions (Abnizova et al., 2012), little is known about the rates of carbon processing and the drivers of such processes in other regions (Downing, 2010). Such a lack of knowledge is particularly critical in arid and semi-arid areas of the world such as the Mediterranean, where temporary ponds are one of the most frequent types of inland water (Sánchez-Carrillo, 2009). A proper characterisation of the carbon fluxes mediated by temporary ponds and other temporary ecosystems in both their emerged and inundated phases is thus a necessary step for detailed regional carbon budgeting in these areas. In particular, carbon effluxes from the water body are a key component of carbon cycling in systems such as temporary ponds, where transport fluxes along aquatic conduits have a minor role in the fate of carbon.

In this study, we examined the intra- and intersystem variability of $\mathrm{CO}_{2}$ effluxes from a set of Mediterranean temporary ponds during the flooding phase, a hot-spot for biogeochemical cycling in temporary systems (Huxman et al., 2004; Valett et al., 2005; Jenerette et al., 2008). We expected the areal $\mathrm{CO}_{2}$ effluxes to be comparable to or even higher than typical effluxes from other Mediterranean stagnant aquatic ecosystems. Finally, we investigated whether the $\mathrm{CO}_{2}$ effluxes in the ponds were determined by properties of the surrounding catchment or dominated by the intrinsic properties of each pond.

\section{MATERIALS AND METHODS}

\section{Study sites}

We studied a total of 12 temporary ponds located on the island of Menorca $\left(39^{\circ} 56^{\prime} \mathrm{N}, 4^{\circ} 6^{\prime} \mathrm{E}, \mathrm{Ba}-\right.$ learic Islands, Western Mediterranean). The climate is Mediterranean, with a dry and hot summer period. The mean monthly temperatures range from $10^{\circ} \mathrm{C}$ in January to $25^{\circ} \mathrm{C}$ in August. The mean annual precipitation is $549 \mathrm{~mm}$ and is typically concentrated in autumn and winter, with November the most humid month and July the driest. The ponds were selected from a detailed inventory of these systems on the island (Fraga et al., 2010) to cover the widest possible spectrum of physicochemical (Pretus et al., 2010), geomorphologic (Cardona et al., 2010) and hydrological properties (Estaún et al., 2010). Thus, the selected ponds range widely in terms of environmental properties (Table 1).

\section{Field and laboratory methods}

The study was conducted during the flooding phase of the ponds in November 2013. A cumulative rainfall of $130 \mathrm{~mm}$ was recorded from the end of the dry phase (September) until the sampling campaign. The $\mathrm{CO}_{2}$ efflux or exchange of $\mathrm{CO}_{2}$ with the atmosphere $\left(F_{\mathrm{CO}_{2}}\right)$ was measured in both the inundated and emerged sections of 


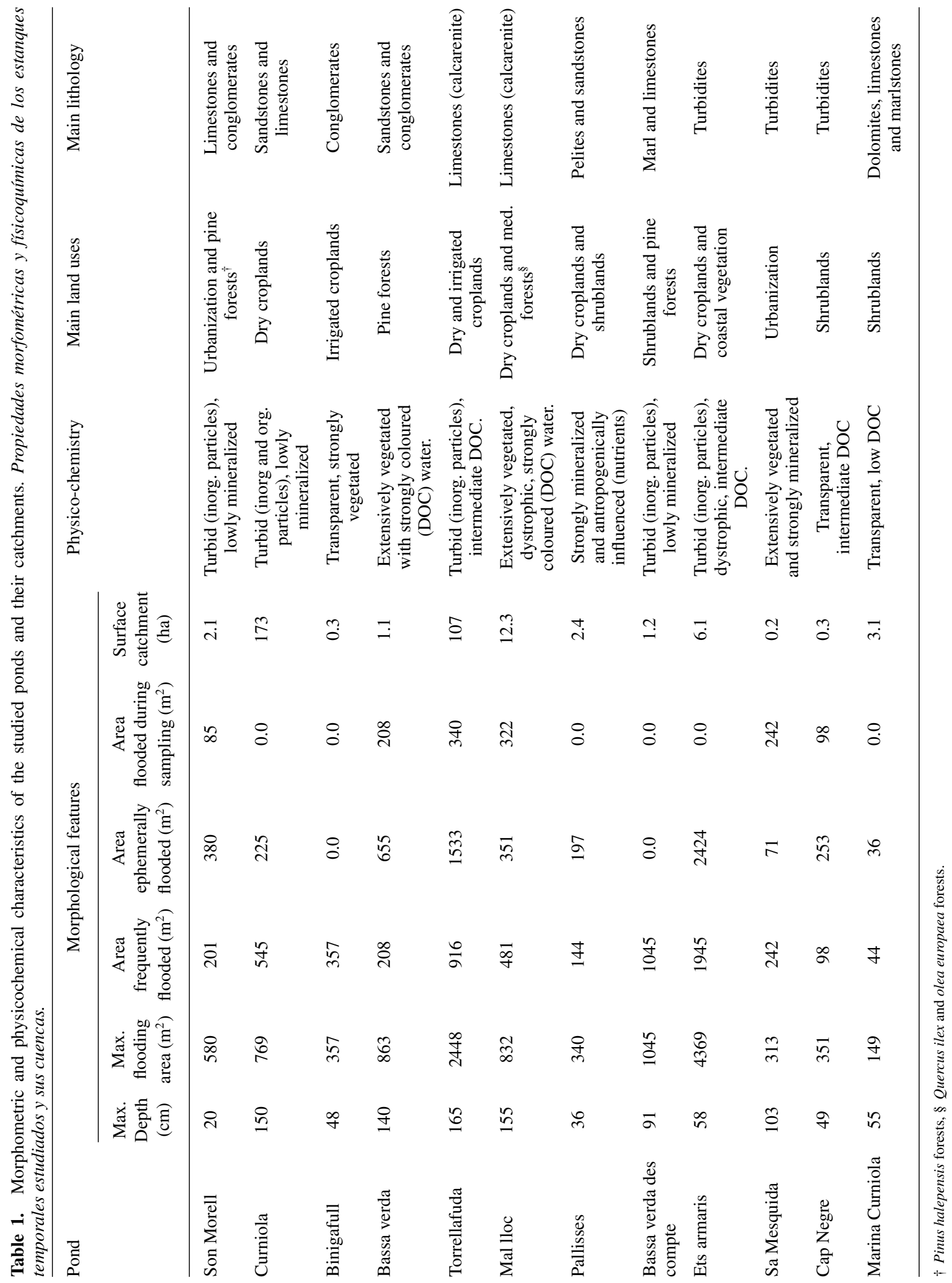



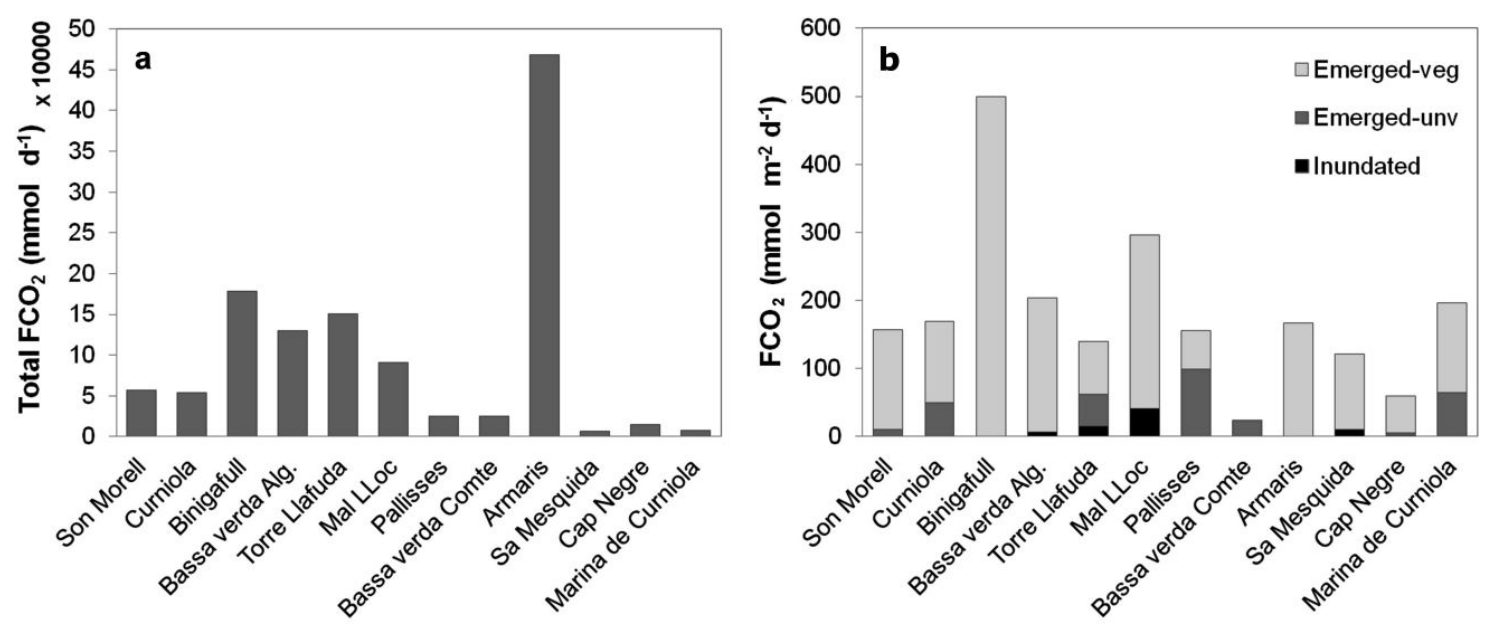

Figure 1. $\mathrm{CO}_{2}$ effluxes from the studied temporary ponds. a) total flux, b) areal flux by sections. Flujos de CO 2 desde los estanques temporales. a) flujo total, b) flujo por unidad de superficie para cada sección.

each pond. In the emerged section, the measurements distinguished between vegetated and nonvegetated areas. This nomenclature will be used throughout the text to refer to the different sections of the ponds.

\section{Characterisation of the ponds}

At each pond, the surface area of each section was measured in situ both manually and using a GPS and afterwards digitised with the help of aerial photography and based on the cartographic data in Fraga et al. (2010). The organic content of emerged and inundated sediments was determined by loss on ignition (Dean, 1974) on triplicate samples. Plant biomass as small roots was included in the organic content determination. Mean altitude, mean slope, lithologies, soil types, land cover and total area in the catchment of each pond as well as in a $500 \mathrm{~m}$ buffer around the pond were determined by geographic information systems (GIS) data layers obtained from Fraga et al. (2010). The layers were combined using QGIS (Quantum GIS Development Team, 2014).

\section{$\mathrm{CO}_{2}$ effluxes}

The $F_{\mathrm{CO}_{2}}$ was measured in situ at the inundated, emerged-unvegetated and emerged-vegetated sections of each pond. Three replicate flux mea- surements were performed at each section using an opaque enclosed chamber connected to an infrared gas analyser (IRGA model EGM-4, PP-Systems, Amesbury, USA). The chamber method allows accurate direct measurements of $\mathrm{CO}_{2}$ emissions from either water or terrestrial surfaces. The floating chamber for air-water flux measurements (inundated section) had a surface area of $0.194 \mathrm{~m}^{2}$ and a volume of $27.1 \mathrm{~L}$. The chamber for flux measurements in emerged sediments (vegetated and unvegetated sections) had a surface area of $0.0078 \mathrm{~m}^{2}$ and a volume of 1.171 L (model SRC-1, PP-Systems, Amesbury, USA). Flux measurements in emerged sediments corresponded to $\mathrm{CO}_{2}$ emissions including both soil and root respiration. In all cases, the $\mathrm{CO}_{2}$ concentration in the closed air volume of the chambers was monitored every $4.8 \mathrm{~s}$, with an accuracy of $1 \%$. The flux measurements lasted until at least $10 \mu \mathrm{atm}$ of change in $\mathrm{CO}_{2}$ were reached, with a maximum duration of $600 \mathrm{~s}$ in water (minimum of $300 \mathrm{~s}$ ) and of $300 \mathrm{~s}$ in emerged sediments (minimum of $120 \mathrm{~s}$ ). The triplicate measurements in the vegetated and unvegetated sections were randomly distributed within each section. At each chamber location, sediment temperature and humidity were measured with portable sensors (ECH2O 10HS, Decagon, USA and Hi93500, Hannah, USA). During water flux measurements, air temperature and wind speed 
at $2 \mathrm{~m}$ were monitored continuously with an anemometer (Kestrel 4500, Nielsen-Kellerman Boothwyn, USA) mounted on a tripod.

The gas flux for each chamber measurement was calculated from the slope of the linear regression between the $\mathrm{CO}_{2}$ concentration in the chamber and time $\left(R^{2}>0.9\right)$, correcting for temperature and atmospheric pressure (Lambert \& Fréchette, 2005). The gas flux for each section was expressed in mmol m $\mathrm{m}^{-2} \mathrm{~d}^{-1}$, with the convention that positive fluxes correspond to $\mathrm{CO}_{2}$ effluxes to the atmosphere.

The total $\mathrm{CO}_{2}$ efflux for each pond $\left(\mathrm{mmol} \mathrm{d}^{-1}\right)$ was calculated by multiplying the mean specific areal flux of each section by the surface area of each section. The mean whole-ecosystem flux of $\mathrm{CO}_{2}\left(\mathrm{E}-\mathrm{F}_{\mathrm{CO}_{2}}\right.$ in mmol m $\left.\mathrm{m}^{-2} \mathrm{~d}^{-1}\right)$ was obtained by dividing the total $\mathrm{CO}_{2}$ flux by the maximum flooding area of each pond (Table 1).

\section{Statistical analyses}

To assess the changes in $\mathrm{CO}_{2}$ fluxes depending on the pond or on the section within each pond, an analysis of variance (ANOVA) was performed. Due to the sensitivity of ANOVA to unbalanced and incomplete designs, we applied the ANOVA to two linear mixed models of the logtransformed data. In the first, we considered the section of the pond as a fixed effect and the ponds as blocks of design (random effects). In the section, we only considered the random effect. To identify differences in effluxes between sections, multiple comparison post-hoc tests (Tukey) of the mixed model were performed.

To examine the influence of the surrounding environment on $\mathrm{CO}_{2}$ fluxes, we performed a principal component analysis (PCA) on the correlation matrix of the main land cover types (\% urban, $\%$ agricultural, $\%$ forest, $\%$ shrubland and $\%$ water bodies), lithologies (calcareous, sandstones and turbidites) and hydromorphology (total area and slope of the catchment). All variables were normalised prior to analysis by $\log 10$ or arcsine $\sqrt{(x)}$ (for percentage data) transformation. The relationship between the catchment variables and $\mathrm{CO}_{2}$ effluxes was then examined using a simple linear regression with the scores of the compo- nents of the PCA as the independent variables and the areal flux of $\mathrm{CO}_{2}$ as the dependent variable. Secondarily, an RDA with the catchment properties and the $\mathrm{CO}_{2}$ effluxes in emerged sediment or water as independent sets of variables was performed to further confirm the results obtained with the PCA.

All the statistical analyses were performed in $\mathrm{R}$ software 3.0.2 (R Core Team, 2013) using the packages nlme (Pinheiro et al., 2013), multcomp (Hothorn et al., 2008) and vegan (Oksanen et al., 2013).

\section{RESULTS}

\section{$\mathrm{CO}_{2}$ effluxes in the ponds}

All the ponds were net emitters of $\mathrm{CO}_{2}$ to the atmosphere. The mean ( \pm standard deviation, SD) ecosystem $F_{\mathrm{CO}_{2}}\left(\mathrm{E}-F_{\mathrm{CO}_{2}}\right)$ was $121.3 \pm 138.1 \mathrm{mmol}$ $\mathrm{m}^{-2} \mathrm{~d}^{-1}$, ranging from 20.1 to $526.1 \mathrm{mmol} \mathrm{m}^{-2}$ $\mathrm{d}^{-1}$ (Fig. 1). Although some ponds contributed substantially to the variability of E- $F_{\mathrm{CO}_{2}}$ among ponds, most ponds had fluxes around the mean value (Fig. 1). The main driver of the contribution to the total pond efflux was the area of the pond, with the largest pond (Armaris) showing the highest effluxes (Fig. 1a). If the values were expressed as areal flux, the differences between ponds diminished (Fig. 1b). Only six of the studied ponds were inundated during the field campaign. However, no significant differences in the areal efflux (mmol m$\left.{ }^{-2} \mathrm{~d}^{-1} ; F=1.3, p>0.05\right)$ or in the total efflux per pond $\left(\mathrm{mmol} \mathrm{d}^{-1} ; F=0.7\right.$, $p>0.05$ ) were found between ponds independently of whether they were flooded.

The ANOVA for the mixed model indicated significant differences in the $\mathrm{CO}_{2}$ flux among the three sections of each pond $(F=45 ; p<0.001)$. Post-hoc tests showed that the efflux was significantly higher in the emerged sections than in the inundated sections of the ponds (Fig. 2; $p<0.001)$. Within the emerged sections, the efflux was higher from vegetated sediments than from unvegetated sediments (Fig. $2 ; p<0.001$ ). Vegetated areas not only had higher relative effluxes (Fig. 1b) but also represented the largest areas within the ponds ( $64 \%$ on average). No 


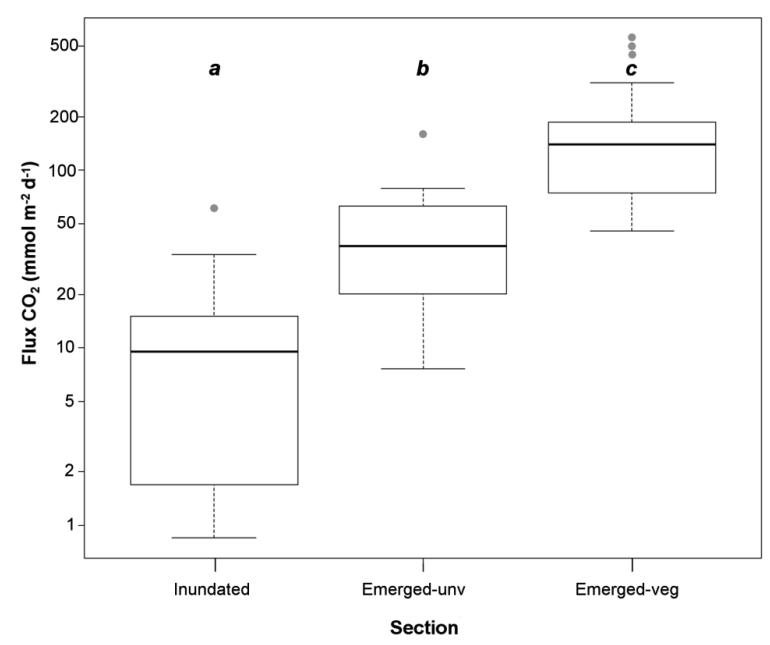

Figure 2. $\mathrm{CO}_{2}$ effluxes from the different sections of the ponds. Data are given in Tukey boxplots. Significant differences between groups ( $p<0.001$, post-hoc tests) are marked with different letters. Flujos de $\mathrm{CO}_{2}$ desde las distintas secciones de los estanques. Boxplots de Tukey, las letras indican diferencias significativas (tests post-hoc, $\mathrm{p}<0.001$ ) entre secciones.

significant relationship was found between the fluxes in the inundated and the emerged sections of the ponds (Fig. 3).

\section{Relationship with the environmental variables}

The two first axes of the PCA with the catchment variables explained $53.2 \%$ of the variance (Fig. 4a), grouping the ponds in three sets. A first set was positively correlated with the first axis: agricultural soil uses, calcareous lithologies and large catchment areas. A second group was positively correlated with the second axis: turbidites lithology and higher percentage of urban areas. Finally, a third group was negatively correlated with both axes: a higher percentage of forested lands, stronger slopes and sandstone lithologies.

The main axes of this PCA were not correlated with the $\mathrm{E}-F_{\mathrm{CO}_{2}}$ of the ponds $\left(\mathrm{mmol} \mathrm{m} \mathrm{m}^{-2}\right.$ $\mathrm{d}^{-1}$; Fig. 4b,c). Complementarily, the RDA confirmed that the $\mathrm{CO}_{2}$ fluxes from emerged sediments or water were not significantly correlated with the set of catchment landscape variables because no environmental variables were significantly correlated with the $\mathrm{CO}_{2}$ effluxes of the ecosystem or the different sections.

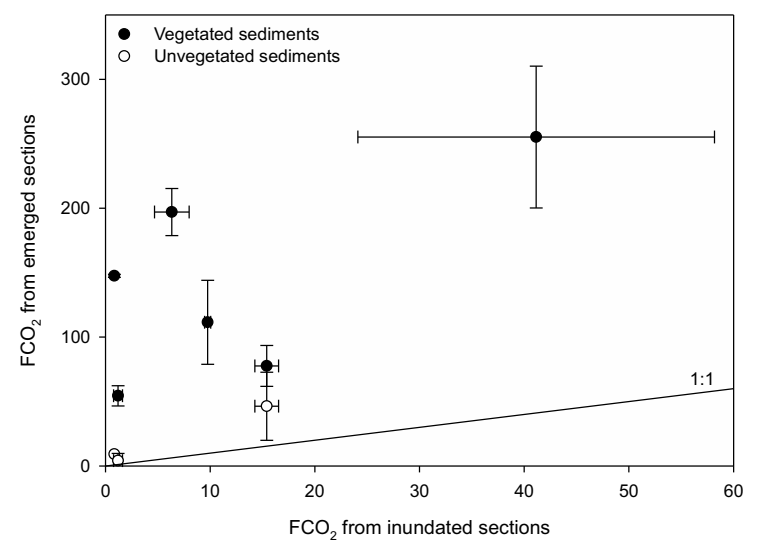

Figure 3. Relationship between the $\mathrm{CO}_{2}$ efflux (in mmol m $\mathrm{m}^{-2}$ $\mathrm{d}^{-1}$ ) from the emerged and inundated sections of the ponds. The 1:1 line is shown for reference. Relación entre el flujo de $\mathrm{CO}_{2}$ (en mmol $\mathrm{m}^{-2} \mathrm{~d}^{-1}$ ) desde las secciones emergidas y inundadas de los estanques. Se muestra la línea 1:1 como referencia.

The E- $\mathrm{F}_{\mathrm{CO}_{2}}$ showed a significant relationship with the mean organic content of sediments (Fig, $5 \mathrm{a} ; R^{2}=0.42 ; p<0.05$ ). Whereas the efflux from the inundated sections was not significantly related to the sediment organic content (Fig. 5b), the efflux from the emerged sections showed a marked relationship with the organic content (Fig. 5c; $R^{2}=0.71 ; p<0.01$ ). No significant relationship was found between the efflux from the emerged sections and the humidity of the emerged sediments $(p>0.05)$.

\section{DISCUSSION}

Our study confirms temporary ponds to be effective carbon processors in the landscape. During their flooding phase, the studied ponds were net emitters of $\mathrm{CO}_{2}$ to the atmosphere, and these efflux rates of $\mathrm{CO}_{2}$ were, moreover, in the upper range for effluxes from freshwater ecosystems (Raymond et al., 2013). Such high fluxes occurred primarily in the extensive emerged sections of the ponds (Fig. 1, Fig. 2). These emerged sediments represented the largest section in the ponds ( $88 \%$ of the area on average) and also presented the highest fluxes of $\mathrm{CO}_{2}$ per area (Fig. 1b). This property explains the much higher ecosystem $\mathrm{CO}_{2}$ fluxes observed here than previously reported for Mediterranean temporary wetlands, where only the aquatic phase was con- 
sidered (Morris et al., 2013). Thus, the relevance of temporary ponds in the carbon fluxes in Mediterranean landscapes will be highly driven by the emerged sections of these environments. Nevertheless, it should be kept in mind that the estimates presented here do not represent the annual net ecosystem exchange of the emerged sediments. During the period of study, the emerged sediments were relatively humid (just rewetted), influenced by the recent precipitation events which may have exacerbated $\mathrm{CO}_{2}$ emissions (hot moment sensu Gallo et al., 2013). Interestingly, the $\mathrm{CO}_{2}$ efflux from these temporary ponds was comparable to the $\mathrm{CO}_{2}$ efflux from Mediterranean soils (median, range $=188,44-371 \mathrm{mmol} \mathrm{m}^{-2} \mathrm{~d}^{-1} ; n=42$; Global soil respiration database (Bond-Lamberty \& Thomson, 2010)). Our results are in line with re-
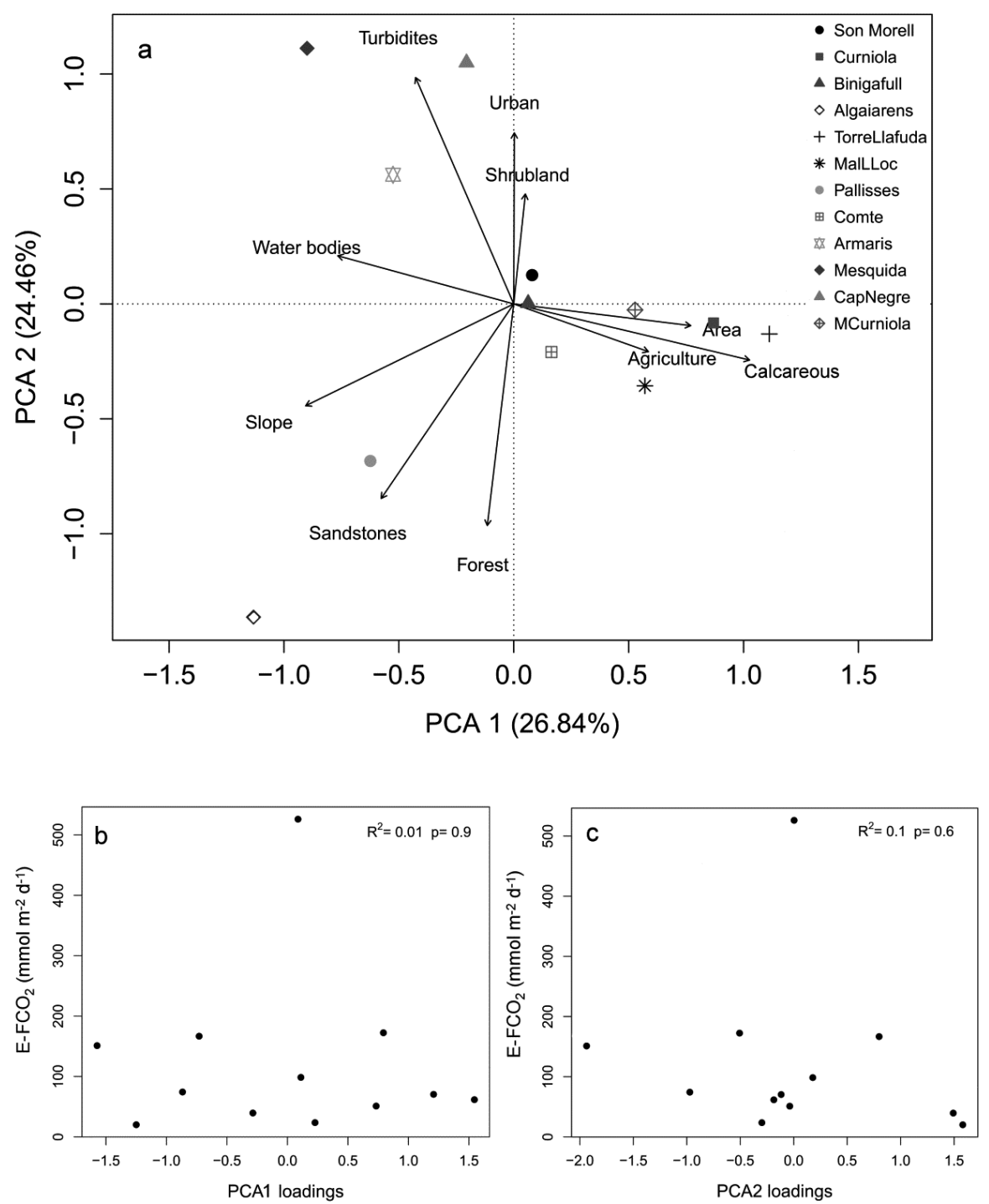

Figure 4. a) Multivariate ordination (principal component analysis) of the catchment properties of the studied ponds. b) Relationship between the first and c) second PCA axis and the ecosystem flux of $\mathrm{CO}_{2}$. a) Ordenación multivariante (análisis de componentes principales) de las propiedades de la cuenca de captación de los estanques estudiados. b) Relación entre el primer y c) segundo componentes principales y el flujo ecosistémico de $\mathrm{CO}_{2}$. 

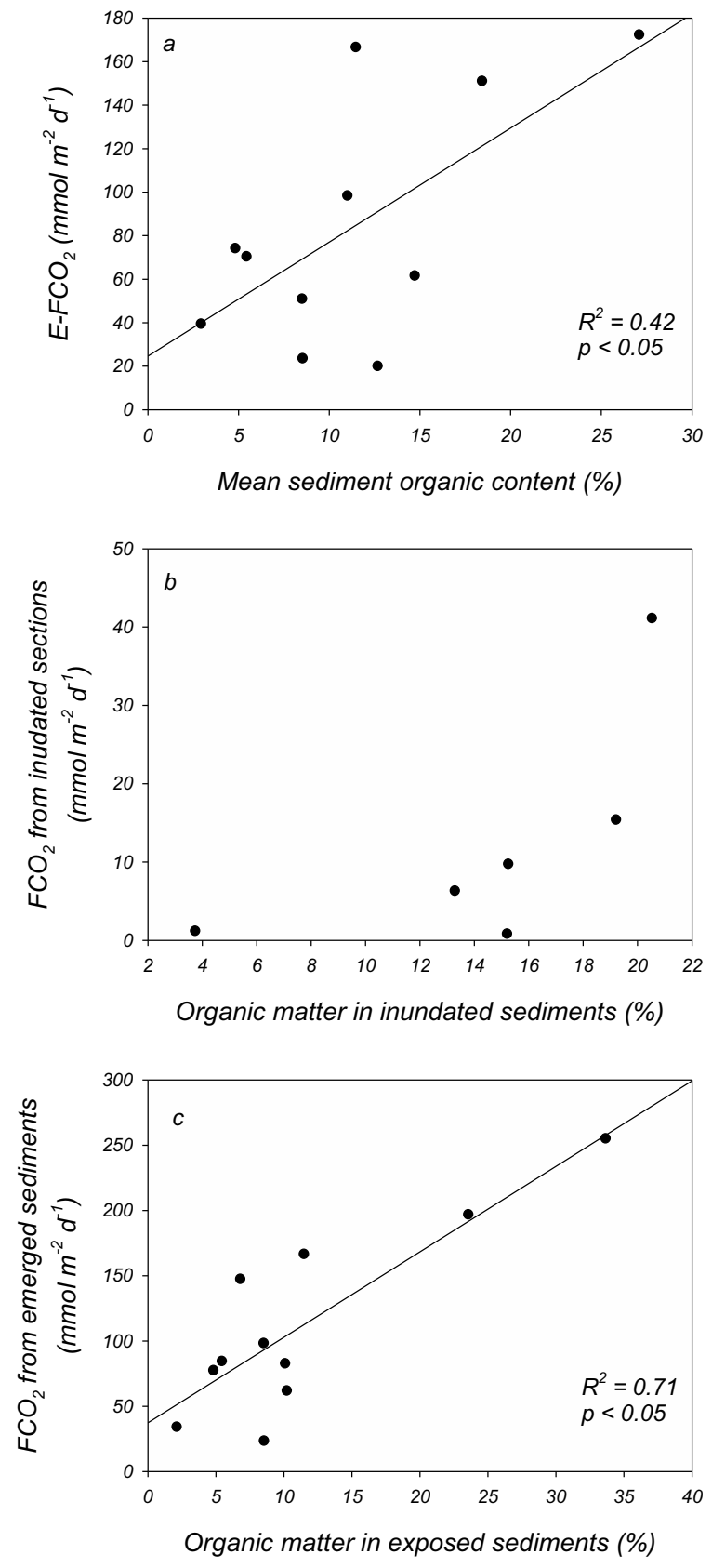

Figure 5. Relationship between $\mathrm{CO}_{2}$ efflux and sediment organic content at an ecosystem scale (a), and for the gas flux from the inundated (b) and emerged sections (c). In a), the organic content is weighted by the surface area of each section. The lines correspond to the significant $(p<0.05)$ linear leastsquares regressions. Relación entre el flujo de $\mathrm{CO}_{2}$ y el contenido orgánico sedimentario a escala ecosistémica (a), y para las secciones inundadas (b) y emergidas (c) de los estanques. En a), el contenido orgánico está ponderado por la superficie de cada sección. Las líneas corresponden a las regresiones lineales (mínimos cuadrados) significativas $(\mathrm{p}<0.05)$. sults from inundated wetlands, where increases in $\mathrm{CO}_{2}$ effluxes after drying have been widely reported (Moore \& Knowles, 1989, Freeman et al., 1993, Fenner \& Freeman, 2011). Moreover, our results agree with recent observations on $\mathrm{CO}_{2}$ effluxes from dry river beds (von Schiller $e t$ al., 2014). Overall, these results emphasise the overlooked importance of the emerged sections of temporary freshwater ecosystems in terms of $\mathrm{CO}_{2}$ effluxes.

The variability in the $F_{\mathrm{CO}_{2}}$ among sections of the ponds was higher than the variability among ponds. The higher $F_{\mathrm{CO}_{2}}$ observed in the emerged sections compared with that from the inundated sections might be related to a physical limitation of gas diffusion in the latter. In the inundated sections, the $\mathrm{CO}_{2}$ must diffuse through the water column to reach the atmosphere, and gas efflux is finally determined by wind-driven turbulence in the boundary layer (Bade, 2009). On the contrary, in emerged sediments, gas diffusion is not limited by the existence of a water column.

The higher fluxes observed in the vegetated than in the unvegetated sections of emerged sediments might be related to root respiration. Root respiration can reach up to half of the total soil respiration in vegetated soils (Andrews et al., 1999; del Grosso et al., 2005). Additionally, other root-linked processes such as microbial respiration in the rhizosphere could also play an important role on enhancing the $\mathrm{CO}_{2}$ efflux from vegetated soils (Luo \& Zhou, 2006).

The lack of relationship between the effluxes from inundated and emerged sections indicates that the drivers of fluxes in the different sections of the ponds are not necessarily the same (Fig. 3) and, accordingly, that the magnitude of the fluxes in the different sections of the pond will not necessarily follow the same direction spatially or temporally.

\section{Can the $\mathrm{F}_{\mathrm{CO}_{2}}$ at the system level be defined by watershed properties?}

Small aquatic systems with high watershed-tosystem area ratios are expected to be highly dependent on external drivers (Álvarez-Cobelas et al., 2005). We found that catchment charac- 
teristics, such as land use or lithology, were not related to the $\mathrm{E}-\mathrm{F}_{\mathrm{CO}_{2}}$ fluxes from the studied ponds. This apparently poor influence of the catchment characteristics on the $\mathrm{CO}_{2}$ effluxes persisted when the effluxes were considered separately by emerged and inundated sections. On the contrary, the differences in $\mathrm{CO}_{2}$ effluxes between ponds were most likely related to intrinsic properties of the pond. Among these, organic matter quality and quantity and nutrient availability will most likely play a key role in determining the system's heterotrophic metabolism. In the studied ponds, the efflux at a system level was significantly correlated with the organic content of the sediments (Fig. 5a), representing $40 \%$ of the variance in the fluxes. The sedimentary organic content was in accordance with mean values in wetlands, temporary ponds and lagoons (Mitsch \& Gosselink, 2007; Florencio et al., 2009, Obrador \& Pretus, 2013). Interestingly, only the emerged sections maintained the relationship between $\mathrm{CO}_{2}$ flux and sediment organic content, whereas the fluxes from the inundated sections were independent of this. The lack of relationship for the inundated sections might be due to a different gas exchange between the water and the atmosphere but also to the respiration of dissolved organic carbon in the water column. Thus, effluxes from inundated sections would more likely be related to the dissolved organic matter than to the sediment organic matter. The characterisation of the organic matter component, either dissolved or particulate, in these systems might furnish an insight into the links between mineralisation and consequent flux and the organic matter present, especially in the inundated sections of the ponds. Further work on the quality and concentration of DOM in the water column of the ponds is needed to assess this relationship.

\section{CONCLUSIONS}

The temporary ponds exhibited high $\mathrm{CO}_{2}$ fluxes per unit area during the flooding phase. Most of these effluxes occurred in the emerged sections, especially in those areas with vegetation.
This finding demonstrates the need to include the emerged sections when incorporating the effects of temporary systems on $\mathrm{CO}_{2}$ effluxes, a pattern to recognise not only in temporary ponds but in other fluctuating systems such as dry river beds, dry reservoir belts or wetlands.

Although the fluxes from the ponds were not related to the properties of their catchments at an ecosystem scale or by sections, the significant relationship between the organic content of sediments and these effluxes highlights the need for a deep characterisation of the organic matter in these environments. This characterisation would be a fundamental step in determining the main drivers of carbon efflux from temporary ponds at a local scale and for upscaling to regional carbon budgets.

\section{ACKNOWLEDGEMENTS}

This study was funded by the Institute Menorquí d'Estudis (Menorca, Spain) and conducted with the support of the Spanish Ministry of Science (project Carbon transport and use through river networks: the relevance of global change (CARBONET), CGL2011-30474-C02-01, 02). NC held a post-doctoral grant from the Wenner-Gren Foundation (Sweden). DvS was additionally funded by a "Juan de la Cierva" postdoctoral grant (jci-2010-06397) from the Spanish Ministry of Economy and Competitiveness. Finally, we wish to express our thanks for all the information and help provided by the personnel of the LIFE-BASSES project.

\section{REFERENCES}

ABNIZOVA, A., J. SIEMENS, M. LANGER \& J. BOIKE. 2012. Small ponds with major impact: The relevance of ponds and lakes in permafrost landscapes to carbon dioxide emissions. Global Biogeochemical Cycles, 26: GB2041.

ÁLVAREZ-COBELAS, M., C. ROJO \& D.G. ANGELER. 2005. Mediterranean limnology: current status, gaps and the future. Journal of Limnology, 64: 13-29.

ANDREWS, J. A., K. G. HARRISON, R. MATAMALA \& W. H. SCHLESINGER. 1999. Sepa- 
ration of root respiration from total soil respiration using carbon-13 labeling during free-air carbon dioxide enrichment (FACE). Journal of the Soil Science Society of America, 63: 1429-1435.

BADE, D. 2009. Gas exchange at the air-water interface. In. Biogeochemistry of inland waters. G. E. Likens (ed.): 28-36. Academic Press.

BOND-LAMBERTY, B. \& A. THOMSON. 2010. A global database of soil respiration data. Biogeosciences, 7: 1915-1926.

CARDONA, E., P. FRAGA, I. ESTAÚN, E. TORRES \& J. MASCARÓ. 2010. Les basses temporals a Menorca. In. LIFE Basses: gestió i conservació a Menorca. P. Fraga, I. Estaún \& E. Cardona (eds.): 41-52. Maó: Institut Menorquí d'Estudis.

DEAN, W. 1974. Determination of carbonate and organic matter in calcareous sediments and sedimentary rocks by loss on ignition: comparison with other methods. Journal of Sedimentary Research, 44: 242-248.

DEAN, W. E. \& E. GORHAM. 1998. Magnitude and significance of carbon burial in lakes, reservoirs, and peatlands. Geology, 26: 535-538.

DEL GROSSO, S. J., W. J. PARTON, A. R. MOSIER, E. A. HOLLAND, E. PENDALL, D. S. SCHIMEL \& D. S. OJIMA. 2005. Modeling soil $\mathrm{CO}_{2}$ emissions from ecosystems. Biogeochemistry, 73: 7191.

DOWNING, J. A. 2009. Plenary lecture global limnology: Up-scaling aquatic services and processes to planet Earth. Verh Internat Verein Limnol, 30: 1149-1166.

DOWNING, J. A. 2010. Emerging global role of small lakes and ponds: little things mean a lot. Limnetica, 1: 9-24.

DOWNING, J. A., Y. T. PRAIRIE, J. J. COLE, C. M. DUARTE, L. J. TRANVIK, R. G. STRIEGL, W. H. MCDOWELL, P. KORTELAINEN, N. F. CARACO, J. M. MELACK, \& J. J. MIDDELBURG. 2006. The global abundance and size distribution of lakes, ponds, and impoundments. Limnology and Oceanography, 51: 2388-2397.

DOWNING, J. A., J. J. COLE, J. J. MIDDELBURG, R. G. STRIEGL, C. M. DUARTE, P. KORTELAINEN, Y. T. PRAIRIE \& K. A. LAUBE. 2008. Sediment organic carbon burial in agriculturally eutrophic impoundments over the last century. Global Biogeochemical Cycles 22, GB1018.

ESTAÚN, I., J. MASCARÓ, P. FRAGA, E. CARDONA \& E. TORRES. 2010. Hidroperíode de les basses temporals de Menorca. In: LIFE Basses: gestió $i$ conservació a Menorca. P. Fraga, I. Estaún \& E. Cardona (Eds.): 101-122. Maó: Institut Menorquí d'Estudis.

FENNER, N. \& C. FREEMAN. 2011. Droughtinduced carbon loss in peatlands, Nature Geosciences, 4: 895-900.

FLORENCIO, M., C. GÓMEZ-RODRÍGUEZ, A. GÓMEZ, M. REINA, E. GUTIÉRREZ, P. SILJESTRÖM, L. SERRANO \& C. DÍAZ-PANIAGUA. 2009. Towards a quantitative classification of temporary ponds in Doñana (SW Spain). In: International conference on Mediterranean temporary ponds. Fraga P. (ed.): 83-92. Consell Insular de Menorca, Maó.

FRAGA, P., I. ESTAÚN, E. CARDONA, J. MASCARÓ \& E. TORRES. 2010. Catàleg de basses temporals de l'illa de Menorca. In. LIFE Basses: gestió i conservació a Menorca. P. Fraga, I. Estaún \& E. Cardona (Eds.): 499-654. Maó: Institut Menorquí d'Estudis.

FREEMAN, C., M. A. LOCK \& B. REYNOLDS. 1993. Fluxes of $\mathrm{CO}_{2}, \mathrm{CH}_{4}$ and $\mathrm{N}_{2} \mathrm{O}$ from a Welsh peatland following simulation of water table drawdown: Potential feedback to climatic change. Biogeochemistry, 19: 51-60.

GALLO, E. L., K. A. LOHSE, C. M. FERLIN, T. MEIXNER, \& P. D. BROOKS. 2013. Physical and biological controls on trace gas fluxes in semi-arid urban ephemeral waterways. Biogeochemistry, 119

HOTHORN, T., F. BRETZ \& P. WESTFALL. 2008. Simultaneous Inference in General Parametric Models. Biometrics Journal, 50: 346-363.

HUXMAN, T. E., K. A. SNYDER, D. TISSUE, A. J. LEFFLER, K. OGLE, W. T. POCKMAN, D. R. SANDQUIST, D. L. POTTS \& S. SCHWINNING. 2004. Precipitation pulses and carbon fluxes in semi-arid and arid ecosystems. Oecologia, 141:254-268.

JENERETTE, G. D., R. L. SCOTT \& T. E. HUXMAN. 2008. Whole ecosystem metabolic pulses following precipitation events. Functional Ecology, 22: 924-930.

KORTELAINEN, P., M. RANTAKARI, J. T. HUTTUNEN, T. MATTSSON, J. ALM, S. JUUTINEN, T. LARMOLA, J. SILVOLA \& P. MARTIKAINEN. 2006. Sediment respiration and lake trophic state are important predictors of large $\mathrm{CO}_{2}$ evasion from small boreal lakes. Global Change Biology, 12: 1554-1567. 
LAMBERT, M. \& J. L. FRÉCHETTE. 2005. Analytical techniques for measuring fluxes of $\mathrm{CO}_{2}$ and $\mathrm{CH}_{4}$ from hydroelectric reservoirs and natural water bodies. In: Greenhouse Gas Emissions-Fluxes and Processes. Hydroelectric Reservoirs and Natural Environments. Tremblay, A., L.Varfalvy, C. L. Roehm \& M. Garneau (Eds.): 37-60. Berlin, Springer.

LUO, Y. \& X. ZHOU. 2006. Soil Respiration and the Environment. Academic Press.

MIRACLE, M. R., B. OERTLI, R. CÉRÉGHINO \& A. HULL. 2010. Preface: conservation of european ponds-current knowledge and future needs. Limnetica, 29: 1-8.

MITSCH, W. J. \& J. G. GOSSELINK. 2007. Wetlands. John Wiley.

MOORE, T. R. \& R. KNOWLES. 1989. The influence of water table levels on methane and carbon dioxide emissions from peatland soils. Canadian Journal of Soil Science, 69: 33-38.

MORRIS, E. P., S. FLECHA, J. FIGUEROLA, E. COSTAS, G. NAVARRO, J. RUIZ, P. RODRIGUEZ \& E. HUERTAS. 2013. Contribution of Doñana wetlands to carbon sequestration. Plos One, 8: e71456.

OBRADOR, B. \& J. L. PRETUS. 2013. Carbon and oxygen metabolism in a densely vegetated lagoon: implications of spatial heterogeneity. Limnetica 32: 321-336.

OKSANEN, J., F. G. BLANCHET, R. KINDT, P. LEGENDRE, P. R. MINCHIN, R. B. O'HARA et al. 2013. vegan: Community Ecology Package. $R$ package version 2.0-10. http://CRAN.R-project.org/package=vegan

PINHEIRO, J., D. BATES, S. DEBROY, D. SARKAR and the R Development Core Team. 2013. nlme: Linear and Nonlinear Mixed Effects Models. R package version 3.1-111.

PRETUS, J. LL., B. OBRADOR, L. CAÑAS, S. PONS \& B. MOYÀ. 2010. Catàleg de basses temporals de l'illa de Menorca. In. LIFE Basses : gestió i conservació a Menorca. Fraga P., I. Estaún \& E. Cardona (Eds.): 79-100. Maó: Institut Menorquí d'Estudis.

QUANTUM GIS DEVELOPMENT TEAM. 2014. Quantum GIS Geographic Information System. Open Source Geospatial Foundation Project. http: //qgis.osgeo.org

RAYMOND, P. A., J. HARTMANN, R. LAUERWALD, S. SOBEK, C. MCDONALD, M. HOOVER, et al. 2013. Global carbon dioxide emissions from inland waters. Nature, 503: 355-359.

R CORE TEAM (2013). R: A language and environment for statistical computing. R Foundation for Statistical Computing, Vienna, Austria. URL http://www.R-project.org/.

SÁNCHEZ-CARRILLO, S. 2009. Hydrology and biogeochemistry of Mediterranean temporary ponds. In: International conference on Mediterranean temporary ponds. Fraga P. (ed.): 71-82. Consell Insular de Menorca, Maó.

VON SCHILLER, D., R. MARCÉ, B. OBRADOR, LL. GÓMEZ-GENER, J. P. CASAS, V. ACUÑA \& M. KOSCHORRECK. 2014. Carbon dioxide emissions from dry watercourses. Inland Waters, 4: 377-382.

VALETT, H. M., M. A. BAKER, J. A. MORRICE, C. S. CRAWFORD, M. C. MOLLES, C. N. DAHM et al. 2005. Biogeochemical and Metabolic Responses to the Flood Pulse in a Semiarid Floodplain. Ecology, 86: 220-234.

WILLIAMS, D. 1997. Temporary ponds and their invertebrate communities. Aquatic conservation: marine and freshwater ecosystems, 7: 105-117. 